\title{
GMO Safety Assessment-Feasibility of Bioassay to Detect Allelopathy Using Handy Sandwich Method in Transgenic Plants
}

\author{
Katsuaki Ishii ${ }^{1}$, Akiyoshi Kawaoka ${ }^{2}$ and Toru Taniguchi ${ }^{1}$ \\ ${ }^{1}$ Forest Bio-Research Center, Forestry and Forest Products Research Institue \\ 2Nippon Paper Institute, Pulp and Paper Research Laboratory \\ Japan
}

\section{Introduction}

Recently, there are many reports on production and field test of transgenic plants including forest trees (Hinchee et al., 2011, Kole and Hall, 2008, Walter et al., 2004). However there are arguments and delicate matters about field release of transgenic trees concerning the influence to environment (McLean and Charrest, 2000). Regulations on recombinant DNA plant biotechnology were developed in USA, Canada, Europe, Oceania, China and Japan (Strauss, 2003, Kalaitzandonakes, 2004, Redenbaugh and McHughen, 2004, Lu \& Hu, 2011, Watanabe et al., 2004) as well as in international agreement (Strauss et al., 2009). The Conference of the Parties 9 meeting held in Milan 2003 decided recognizing host parties evaluate risks associated with the use of genetically modified organisms by afforestaion and reforestation project activities. Risk assessments shall be carried out in a scientifically sound manner and taking into account recognized risk assessment techniques to identify and evaluate the possible adverse effects of living modified organisms on the conservation and sustainable use of biological diversity (Strauss et al., 2009). Environmental safety is considered in speed of degradation of introduced genes in the soil, impact on soil invertebrates like earthworms, impact on aquatic invertebrates like daphnia, impact on beneficial insects like ladybugs, impact on fish, birds, mammals and other plants. Eucalyptus species has in general allelopathy activity like suppression of growth and germination of understory weeds (Zeng et al., 2008). Poplar has also some allelopathy to the crops like wheat or mycorrhizal fungi in the field (Singh et al., 1993, Olsen et al., 1971).

Transgenic trees should be introduced into commerce after they have been critically evaluated for environmental safety. Allelopathy is one of the environmental effects of plants to other plants. It is important to elucidate the effects of the transformations on the allelopathy activity. Here we report the application of a handy sandwich-type bioassay method which was efficient with crop species (Fujii et al., 2003, Golisz et al., 2007) to assess the allelopathy of transgenic aspen trees containing anti-sense peroxidase (prx) (Yahong et al., 2001) and antibiotic (neomycin phosphotransferase ; nptII) (Bevan et al., 1983) gene, and eucalyptus trees containing transcriptional element (Ntlim1) (Kawaoka et al., 2000, 2006) and 
antibiotic (nptII) gene. The purpose of this study is to offer possible screening method to eliminate high allelopathy transformants before field plantation.

This is the first report on application of the new bioassay of handy sandwich method to assess the allelopathy of transgenic aspen and eucalyptus.

\section{Materials and methods}

\subsection{Transgenic trees and control}

Transgenic aspen (Populus sieboldii $\mathrm{x}$ grandidentata)containing anti-sense prx and antibiotic (nptII) gene, and eucalyptus (Eucalyptus camaldulensis) (Fig. 1) containing transcriptional element (Ntlim1) and antibiotic (nptII) gene were used as experimental targets. Both transgenic approaches were intended to create less lignin wood for efficient pulping. Control tree of aspen was the same clone Y-63 which was transformed, and that of eucalyptus was seedling of same species.

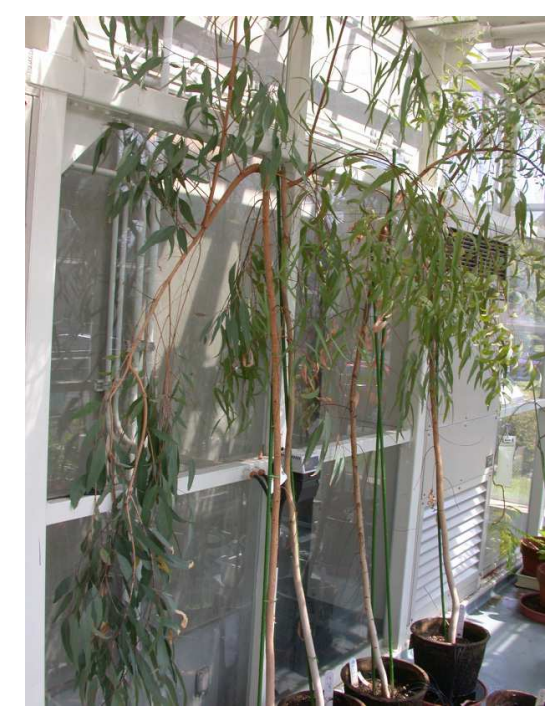

Fig. 1. Transgenic Eucalyptus camaldulensis.

\subsection{Confirmation of transcription of introduced genes}

RNA was extracted from leaves and stems of individual transformants with a QIAGEN RNeasy Plant Mini Kit (QIAGEN, Hilden, Germany) according to the protocol provided by the manufacturer using lysis buffers which contains guanidine thiocyanide and RNA adsorption membrane. One microgram of total RNA was reverse transcribed and then the cDNA amplified with a QIAGEN One Step RT-PCR Kit (QIAGEN, Hilden, Germany) according to the protocol provided by the manufacturer. The oligonucleotide primers used for RT-PCR were 5'- AAACAATTACCAACACTACC-3' (forward) and 5'ACCTGAAAGGGCAACCAGGT-3' (reverse) with anti-peroxidase gene, and $5^{\prime}$ - 
GAGGCTATTCGGCTATGACT-3' (forward) and 5' ${ }^{\prime}$-AATCTCGTGATGGCAGGTTG-3' (reverse) with npt II gene. Conditions for amplification were reverse transcription at $50{ }^{\circ} \mathrm{C}$ for $30 \mathrm{~min}$, initial PCR activation step at $95{ }^{\circ} \mathrm{C}$ for $15 \mathrm{~min}$ followed by 35 cycles at $94{ }^{\circ} \mathrm{C}$ for 1 $\mathrm{min}, 60^{\circ} \mathrm{C}$ for $1 \mathrm{~min}$, and $72^{\circ} \mathrm{C}$ for $1 \mathrm{~min}$. The amplified fragments of cDNA was subjected to electrophoresis in a $2 \%(\mathrm{w} / \mathrm{v})$ agarose gel and detected with ethidium bromide.

\subsection{Allelopathy level determination by sandwich method}

The sandwich method assays the allelopathic activity of leaches from dried leaves on seed germination and growth of receptor plants such as lettuce (Fujii et al., 2003, 2004). Sandwich method was done according to that of Fujii et al. (2003) and Golisz et al. (2007). They used this bioassay method to screen large number plants to detect allelopathy in the 239 medicinal plant species. They demonstrated this method is a less time-consuming bioassay method and could be used to screen a large number of samples. In our experiment, one year old leaves of the transgenic and control trees of E. camaludulensis and P. sieboldii $x$ grandidentata grown in the containment green house were collected and oven-dried at $60{ }^{\circ} \mathrm{C}$ for over night, and then $50 \mathrm{mg}$ in dry weight of them sandwiched between the layers of 0.5 $\%$ low melting point $\left(31^{\circ} \mathrm{C}\right.$ ) agar in the multi-well dishes (6 wells whose diameter is $35 \mathrm{~mm}$ ). Leaves of 1 year old E. cinerea was also used as reference in the experiment of aspen. Six replicated samples were used for each transformant and control.

Seeds of the lettuce of Great Lakes 366 were sown on the agar bed, and then germinated under constant temperature at $20{ }^{\circ} \mathrm{C}$. Five seeds were sown in each well.After 60 hours incubation in the dark, the length of the hypocotyls and roots was measured respectively. The inhibition rate by comparing that of control (water) was considered as allelopathy level of each sample, i.e. less growth rate indicates the high allelopathy level. Buckwheat might be also used as an indicator plant of allelopathy like lettuce (Fig. 2).

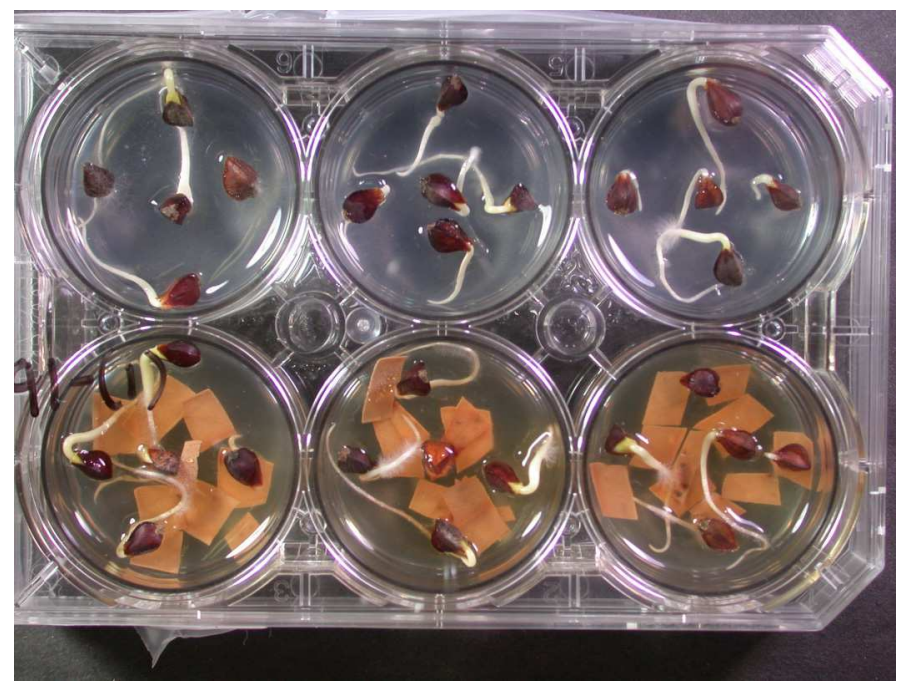

Fig. 2. Six-well multidish plastic plate used for sandwich method. 


\subsection{Statistical analysis}

Analysis of variance (ANOVA) with allelopathy (indicated as growth rate of bioassay plant) was carried out by Fisher's test. Average values were compared using a two-sided t-test.

\section{Results and discussion}

It was checked by RT-PCR that transferred antibiotic genes were still expressed in the leaves and stems of transgenic trees. However, anti-sense gene of peroxidase was only expressed in the stems of transgenic trees. These results are explained that a promoter for antibiotic gene was $35 \mathrm{~S}$ of cauliflower mosaic virus and that for peroxidase was a promoter from aspen peroxidase relating to xylogenesis.

There are slight variations of allelopathy level indicated by this bio-assay among different lines of transgenic trees. In the transgenic aspen, sandwich bio-assay evaluated by lettuce root length inhibition indicated that allelopathy of transgenic materials varied from 22 to $37 \%$ while control was $29 \%$ (Fig. 3). These may be of some effects of different production level of metabolic substances in the similar way like other transgenic aspen where the concentrations of total flavonoids, quercetin, kaempferol and myricetin derivatives in the leaves were different between control and transgenic trees (Haggman et al., 2003).However, we did not detect statistically significant differences among transgenic and control trees by analysis of variance $(P>0.12)$. In contrast, there was a statistically significant difference between species Populus and Eucalyptus with allelopathy $(\mathrm{P}<0.002)$ which indicated the feasibility of the sandwich method to detect the different allelopathy level between species. E. cinerea had stronger allelopathy than Populus hybrid (Fig.3). There was similar tendency in assessing allelopathy level of transgenic and nontransgenic aspen using hypocotyl growth as an indicator (Fig.4). When cellulose rich transgenic white poplar (Populus alba) introduced with bacterial xyloglucanase gene was compared with non-transgenic control, sandwich method revealed no statistical difference between them $(\mathrm{J}-\mathrm{BCH}, 2007)$.

In the case of transgenic eucalyptus, allelopathy levels of transgenic materials were from 17 to $66 \%$ while controls were from 17 to $26 \%$ (Figs. 5).Among transgenic lines, (2)-4 was the lowest allelopathy tree which indicated the statistically significant difference from other lines and controls $(\mathrm{P}<0.01)$. However, part of the variation in allelopathy level may be not only from transformation but also from different genetic background caused by seedling materials.Average allelopathy level of eucalyptus was higher than that of aspen as $28 \%$ versus $31 \%$ indicated as average growth rate to water culture. In the case of salttolerant transgenic Eucalyptus camaldulensis, there was no substantial variation between nontransgenic and transgenic lines with respect to the hypocotyl growth and root elongation of lettuce in sandwich method (Kikuchi et al., 2006, 2009).They also conducted the gas chromatographic and high-performance liquid chromatographic analysis to show no qualitative and quantitative difference between the transgenic and nongenetically modified genotypes of Eucalyptus. Bioassay method is superior as the primary assessment method for allellopathy in considering the simplicity, speed, low cost, and reproducibility to chemical instrumental methods.Sandwich method for allelopathy assessment might be useful as one of the criteria of environmental effects of any 
transgenic platns.However, drying many samples at the same time is time consuming. So, for evaluating multiple leaves, modified sandwich method used homogenized fleshy leaf samples instead of drying them (Shimazaki et al., 2009). Chemical changes by modification or processing of some compounds may occur during the process of homogenization which leads enhancement of the effect of the transgenic and nontransgenic plant on the growth of germinating seeds. Even if the chemical changes were induced during sample preparation (drying or homogenization process), it would be thought to reflect the chemical differences between the transgenic and non-transgenic plants (Shimazaki, 2009). In the floricultural plants, the transgenic carnation (Dianthus caryophyllus) expressing flavonoid 3', 5'-hydroxylase gene (Moon series, www.florigene.com), assessing the allelopathic substances was done by lettuce seed germination bioassay tests in soil containing carnation debris (Kikuchi, 2008).For further study, toxicology and allergenicity testing of products from introduced genes should be carried out before commercialization of transgenic plants.

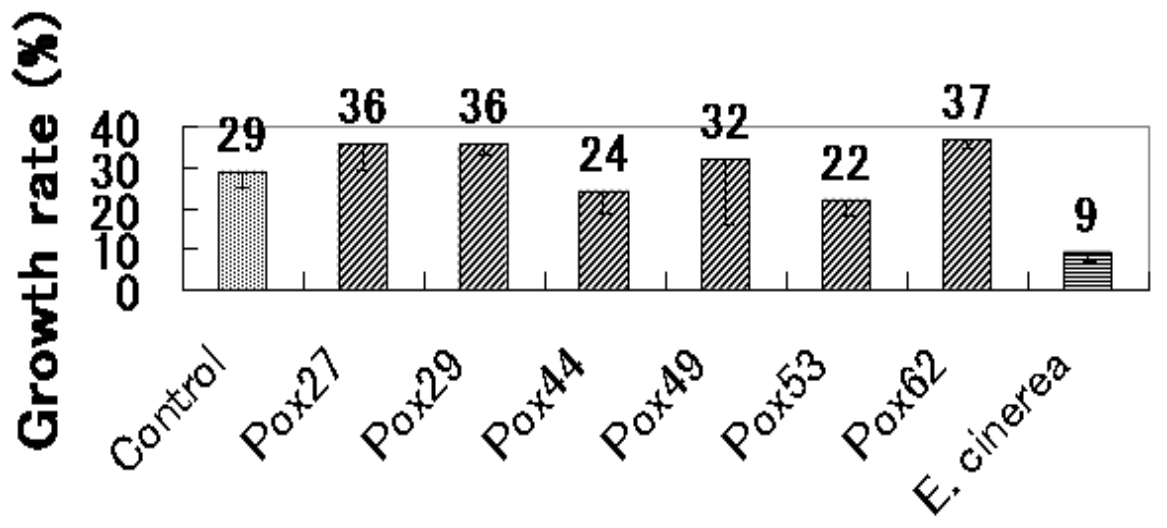

\section{Lines}

Pox 27, 29, 44, 49, 53 and 62; transgenic aspen

E; Eucalyptus cinerea

Bar; standard error

Fig. 3. Allelopathy level of transgenic Populus sieboldii $x$ grandidentata (as $\%$ of lettuce root growth to water medium) 


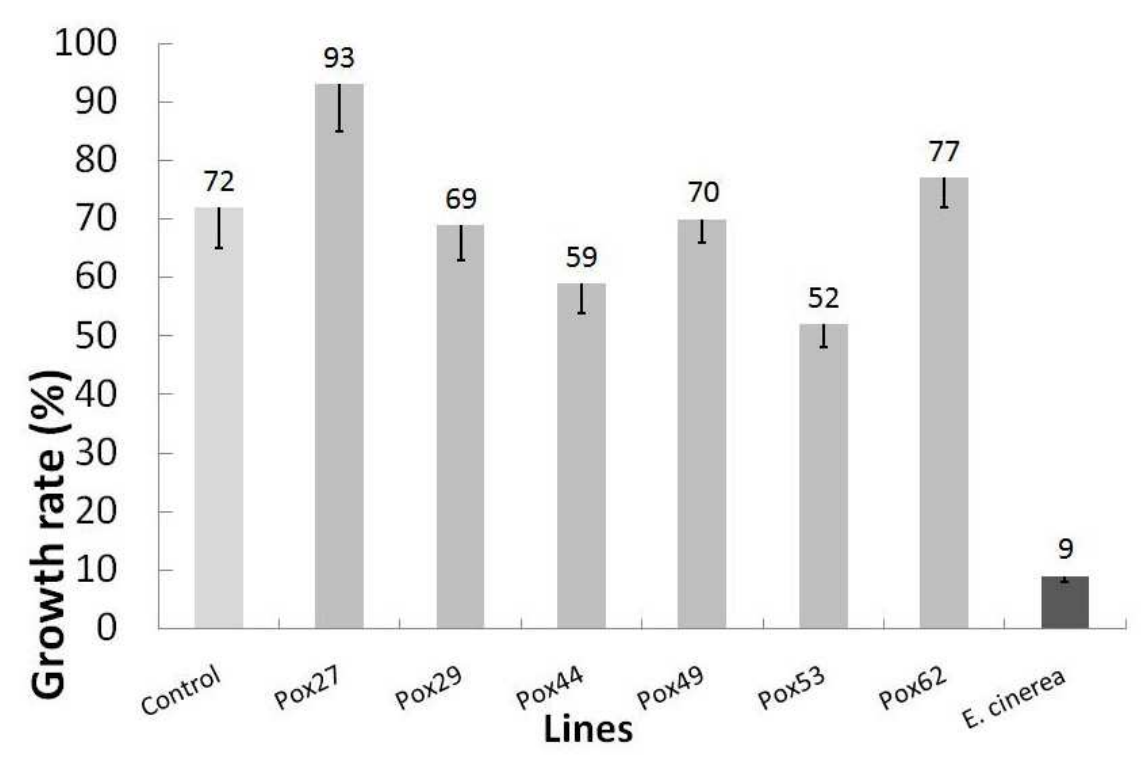

Pox 27, 29, 44, 49, 53 and 62; transgenic aspen E; Eucalyptus cinerea Bar; standard error

Fig. 4. Allelopathy level of transgenic Populus sieboldii x grandidentata (as \% of lettuce hypocotyl growth to water medium)

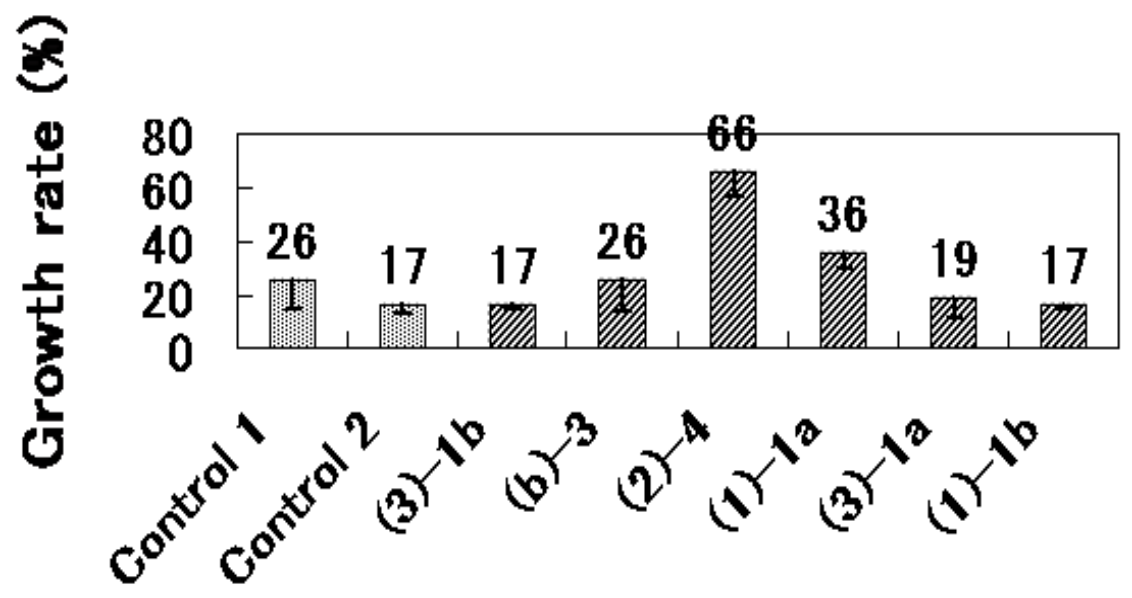

\section{Lines}

Fig. 5. Allelopathy level of transgenic Eucalyptus camaludulensis (as \% of lettuce root growth to water medium)(3)-1b, (b)-3, (2)-4, (1)-1a, (3)-1a and (1)-1b; transgenic eucalyptus Bar; standard error 
Trees have many characteristics that make them more difficult to assess them than those of agricultural crops: they have long life cycle, the production cycle may be 10 to 70 years, pollen moves over enormous distance, there are tremendous genetic and phenotypic variation and ecological complexity (McLean and Charrest, 2000). In the handling of transgenic plants, the key words are "familiarity" and "substantial equivalence". Familiarity is the knowledge of the characteristics of a plant species and the experience with the use of that plant species. Substantial equivalence is that of a novel trait within a particular plant species, in terms of its specific use and safety to the environment and human health, to those in that same species, that are in use and generally considered as safe based on valid scientific rationale. Checking of the allelopathy of transgenic trees is substantial equivalence matter. In the substantial equivalence, we must consider altered weediness potential, gene flow to related species, altered plant pest potential, potential impact on non-target organisms, and potential impact on biodiversity. Allelopathy of transgenic trees may have influence to other plants and biodiversity. The sandwich method can easily detect the high allelopathetic materials. We think, therefore, that it is useful to use this handy sandwich method as one of the criteria for assessing biosafety of plants including forest trees.

\section{Conclusion}

The Cartagena Protocol on Biosafety promulgated guidelines for evaluating the biosafety of living modified organisms (http://www.biodiv.org/biosafety).Transgenic plants should not be planted in the field without an environmental biosafety assessment. Commercial usage and environmental release can be permitted after evaluation in the containment growth room and field. The public concerns of environmental biosafety assessments are to define property of the transgenic plants and assess the influence of the plant on other organisms. Allelopathic influence of transgenic plants must be checked before field release.

Among the methods used for evaluating the allelopathic effects of plants are the dish pack,plant box, sandwich and soil mix methods (Shiomi et al.,1992; Yamaguchi et al., 1994; Sekine et al., 2007). Sandwich method might be one of the most handy and reliable methods for checking the transgenic plants.

\section{Acknowledgment}

We thank Dr. K. Fujii, National Institute for Agro-Environment Institute, for his introduction of sandwich method.We appreciate the kind offer of transgenic aspen from former Prof. N. Morohoshi, Tokyo University of Agriculture and Technology.

\section{References}

Bevan, M.; Flavell, R.B. \& Chilton, M.-D. (1983) A Chimeric Antibiotic Resistance Gene as a Selectable Marker for Plant Cell Transformation. Nature, Vol.304, (February 1983),pp. 184-187. 
Fujii, Y.; Parvez, S.S.; Parvez, M.M.; Ohmae, Y. \& Iida, O. (2003). Screening of 239 Medicinal Plant Species for Allelopathic Activity Using the Sandwich Method. Weed Biology and Management, Vol. 3, pp.233-241

Fujii, Y.; Shibuya, T.; Nakatani, K.; Itani, T.; Hiradate, S; Parvez, M.M. (2004). Assessment Method for Allelopathic Effect from Leaf Litter Leaches. Weed Biology and Management, Vol. 4, pp.19-23

Golisz, A.;Lata, B.;Gawronski, S.W.\&Fujii, Y. (2007)Specific and Total Activities of the Allelochemicals Identified in Buckwheat. Weed Biology and Management,Vol.7, pp. 164-171

Haggman, H.; Frey, A. D.; Ryynanen, L.; Aronen,T.; Julukunen-Tiitto, R.; Tiimonen, H.; Pihakaski-Maunsbach, K.; Jokipii, S.; Chen, H. \& Kallio, P. T. (2003). Expression of Vitreoscilla Haemoglobin in Hybrid aspen (Populus tremula $\mathrm{x}$ tremuloides), Plant Biotechnology Journal, Vol.1,( March 2003), pp. 287-300.

Hinchee, M.; Zhang, C; Chang, S.; Cunningham, M.;Hammond, W.;Nehra, N.; Person, L.(2011). Biotech Eucalyptus can Sustainably Address Society's Need for Wood: the example of Freeze Tolerant Eucalyptus in the Southeastern U.S., IUFRO Tree Biotechnology Conference 2011 "From genomes to integration and delivery" Conference Proceedings Abstracts, pp.438-439, Arraial D’Ajuda,Bahia,Brazil, June 26-July02, 2011

Japan Biosafety Clearing-House (2007). High Cellulose Rich White Poplar trg300-1 and 2 (AaXEG2, Poplus alba L.) . 07-46P-0003 and -0004, 2007-3-22

Kalaitzandonakes, N. (2004). Another Look at Biotech Regulation,Regulation, Vol.27,pp.4450.

Kawaoka, A.; Kaothien, P.; Yoshida, K.; Endo, S., Yamada, K. \& Ebinuma, H.(2000).Functional Analysis of Tobacco LIM Protein Ntlim1 Involved in Lignin Biosynthesis, The Plant Journal, Vol.22, (April 2000), pp.289-301.

Kawaoka, A.; Nanto, K.; Ishii, K. \& Ebinuma, H. (2006). Reduction of Lignin Content by Suppression of the Lim Domain Transcription Factor in Eucalyptus camaldulensis, Silvae Genetica, Vol. 55, (December 2006), pp.269-277.

Kikuchi, A; Kawaoka, A,; Shimazaki, T.; Yu, X.; Ebinuma, H. \& Watanabe, K.N. (2006). Trait Stability and Environmental Biosafety Assessments on Three Transgenic Eucalyptus Lines (Eucalyptus camaldulensis Dehnh, codA 12-5B, codA 12-5C, codA 20-C) conferring salt tolerance. Breeding Research, Vol.8, pp.17-26

Kikuchi, A.; Watanabe, K.; Tanaka, Y.; Kamada, H. (2008). Recent Progress on Environmental Biosafety Assessment of Geneticaly Modified Trees and Floricultural Plants in Japan. Plant Biotechnology, Vol.25, No.1, (March 2008), pp.915, ISSN 1342-4580

Kikuchi, A.; Yu, X.; Shimazaki T., Kawaoka, A.; Ebinuma, H.; Watanabe, K.N. (2009). Allelopathy Assessments for the Environmental Biosafety of the Salt-Tolerant Transgenic Eucalyptus camaldulensis, Genotypes codA 12-5B, codA 12-5C, and codA 20C.J. Wood Science, Vol.55, No.2, (April 2009), pp.149-153

Kole, C. \& Hall, T.C.(2008). Transgenic Forest Tree Species.: Wiley-Blackwell, ISBN 978-14051-6924-0, Oxford, UK 
Lu, M.-Z.; Hu, J.-J. (2011). A Brief Overview of Field Testing and Commercial Application of Transgenic Trees in China. IUFRO Tree Biotechnology Conference 2011 "From genomes to integration and delivery" Conference Proceedings Abstracts, pp.438-439, Arraial D'Ajuda,Bahia,Brazil, June 26-July02, 2011

Mclean, M. A. \& Charrest, P. J.(2000). The Regulation of Transgenic Trees in North America, Silvae Genetica, Vol. 49, (December 2000), pp.233-239

Olsen, R. A.; Odham, G. \& Linderberg, G.(1971). Aromatic Substances in Leaves of Populus tremula Inhibiters of Mycorrhizal Fungi. Physiol. Plant., Vol.25,( March 1971), pp.122-129.

Redenbaugh, K. \& McHughen, A.(2004). Regulatory Challenges Reduce Opportunities for Horticultural Biotechnology, Calif. Agric.,Vol. 58, pp.106-119.

Sekine, T.; Sugano, M.; Majid, A. \& Fujii, Y. (2007). Antifungal Effects of Volatile Compunds from Black Zira (Bunium persicum) and Other Spices and Herbs. J. Chem. Eco. , Vol.33, pp.2123-2132.

Shimazaki, T.; Kikuchi, A.; Matsunaga, E.; Nanto, K.; Shimada, T. \& Watanabe, K.N. (2009). Establishment of a Homogenized Method for Environmental Biosafety Assessments of Transgenic Plants. Plant Biotechnology, Vol.26, No.1, (March 2009), pp.143-148, ISSN 1342-4580

Shiomi, M.; Asakawa, Y.; Fukumoto, F.; Hamaya, E.; Hasebe, A.; Ichikawa, H.; Matsuda, I.; Muramatsu, T.; Okada, M.; Sato, M.; Ukai, Y.; Yokoyama, K.; Motoyoshi, F.; Ohashi, Y.; Ugaki, M. \& Noguchi, K. (1992). Evaluation of the Impact of the Release of Transgenic Tomato Plants with TMV Resistance on the Environment. Bull Natl Inst Agro-Environment Science Jpn., Vol.8, pp.1-51, ISSN 0911-9450

Singh, A.; Danda, R.S. \& Ralham, P.K.(1993). Performance of Wheat Varieties under Poplar Plantation in Panjab,Agroforestry Systems, Vol.22,( February 1993),pp.8386.

Strauss, S.H. (2003). Regulation of Biotechnology as though Gene Function Mattered. BioScience, Vol.53, pp.453-454

Strauss, S.H.; Tan, H.; Boerjan, W. \& Sedjo, R. (2009). Strangled at Birth? Forest Biotech and the Convention on Biological Diversity, Nature Biotechnology, Vol.27, (June 2009), pp.519-527.

Walter, C.; Charity, J.; Donaldson, L.; Grace, L.; Mcdoonald, A., Moller, R. \& Wagner, A. (2004). Genetic Modification of Conifer Forestry: State of the Art and Future Potential- A Case Study with Pinus radiate. In: Kumar S, Fladung M (eds) Molecular Genetics and Breeding of Forest Trees. Food Products Press, pp.215-242, NY, U.S.A.

Watanabe, K. N., Taeb, M \& Okusu, H. (2004).Japanese Controversies over Transgenic Crop Regulation,Science, Vol.305, No.5691,(September 2004), pp1572

Yahong, L.; Tsuji, Y.; Nishikubo, N.; Kajita, S. \& Morohoshi, N. (2001). Analysis of Transgenic Poplar in Which the Expression of Peroxidase Gene is Suppressed. In: Morohoshi N, Komamine A (eds) Molecular Breeding of Woody Plants. Elsevier, Amsterdam-Tokyo, pp.195-204 
Yamaguchi, H. \& Fujii, Y. (1994). Allelopathyc of Cultivated and Weed Azuki Beans Assessment of Allelopathic Activity by Plant Box Method - . J. Weed Science Technology, Vol. 33, pp.138-139, ISSN:0372798X

Zeng, R. S., Mallik, A. U. \& Luos. M. (2008). Allelopathy in Sustainable Agriculture and Forestry. Springer-Verlag, 2008, ISBN 0387773363. 


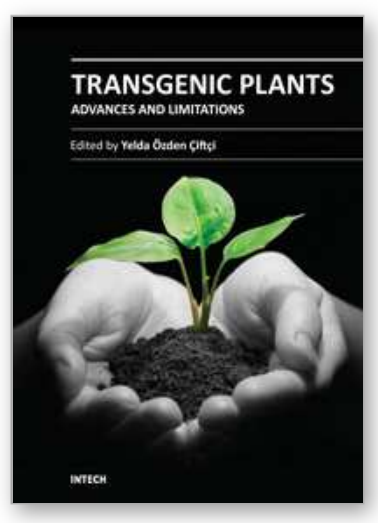

\author{
Transgenic Plants - Advances and Limitations \\ Edited by PhD. Yelda Ozden Çiftçi
}

ISBN 978-953-51-0181-9

Hard cover, 478 pages

Publisher InTech

Published online 07, March, 2012

Published in print edition March, 2012

Development of efficient transformation protocols is becoming a complementary strategy to conventional breeding techniques for the improvement of crops. Thus, Transgenic Plants - Advances and Limitations covers the recent advances carried on improvement of transformation methods together with assessment of the impact of genetically transformed crops on biosafety. Each chapter has been written by one or more experienced researchers in the field and then carefully edited to ensure throughness and consistency.

\title{
How to reference
}

In order to correctly reference this scholarly work, feel free to copy and paste the following:

Katsuaki Ishii, Akiyoshi Kawaoka and Toru Taniguchi (2012). GMO Safety Assessment-Feasibility of Bioassay to Detect Allelopathy Using Handy Sandwich Method in Transgenic Plants, Transgenic Plants - Advances and Limitations, PhD. Yelda Ozden Çiftçi (Ed.), ISBN: 978-953-51-0181-9, InTech, Available from:

http://www.intechopen.com/books/transgenic-plants-advances-and-limitations/gmo-safety-assessmentfeasibility-of-bioassay-to-detect-allelopathy-using-handy-sandwich-method-in-t

\section{INTECH}

open science | open minds

\section{InTech Europe}

University Campus STeP Ri

Slavka Krautzeka 83/A

51000 Rijeka, Croatia

Phone: +385 (51) 770447

Fax: +385 (51) 686166

www.intechopen.com

\section{InTech China}

Unit 405, Office Block, Hotel Equatorial Shanghai

No.65, Yan An Road (West), Shanghai, 200040, China

中国上海市延安西路65号上海国际贵都大饭店办公楼 405 单元

Phone: +86-21-62489820

Fax: +86-21-62489821 
(C) 2012 The Author(s). Licensee IntechOpen. This is an open access article distributed under the terms of the Creative Commons Attribution 3.0 License, which permits unrestricted use, distribution, and reproduction in any medium, provided the original work is properly cited. 